\title{
KARAKTERISTIK EDIBLE FILM YANG DIPRODUKSI DARI KOMBINASI GELATIN KULIT KAKI AYAM DAN SOY PROTEIN ISOLATE
}

\section{CHARACTERISTICS OF EDIBLE FILMS PRODUCED FROM COMBINATION GELATIN SKIN CHICKEN LEGS AND SOY PROTEIN ISOLATE}

\author{
Muhamad Hasdar*, Yuny Erwanto, dan Suharjono Triatmojo \\ Fakultas Peternakan, Universitas Gadjah Mada, Jl. Fauna No. 3, Bulaksumur, Yogyakarta, 55281
}

\section{INTISARI}

Penelitian bertujuan memanfaatkan gelatin kulit kaki ayam yang dikombinasikan dengan soy protein isolate sebagai bahan baku edible film. Materi penelitian adalah gelatin kulit kaki ayam dan soy protein isolate. Penelitian terbagi atas dua tahap yaitu tahap pertama adalah pembuatan gelatin kulit kaki ayam yang direndam dengan $\mathrm{NaOH}$ $0,1 \%$, asam sulfat $0,1 \%$, dan asam sitrat $0,4 \%$. Tahap kedua yaitu pembuatan edible film yang dikombinasikan dengan soy protein isolate pada perbandingan $(75: 25,80: 20,85: 15,90: 10$, dan 95:5). Analisis data mengunakan variansi pola searah, apabila terdapat beda nyata diteruskan uji Duncan's New Multiple Range Test. Profil protein dianalisis dengan SDS-PAGE dan menunjukkan sebagai molekul kolagen. Hasil analisis kandungan asam amino edible film menggunakan HPLC dihasilkan komposisi residu asam amino terbesar adalah glysin yaitu 29,42\%, 37,88\%, 38,32\%, $39,28 \%$ dan 39,17\% pada masing-masing perlakuan. Hal itu menggambarkan bahwa profil protein edible film dapat dipastikan sebagian besar berasal dari kolagen gelatin. Pengamatan dengan scaning electron microscope menunjukkan telah terbentuk cross linking antara molekul protein gelatin dan molekul soy protein isolate dan yang ditunjukan semakin berkurangnya retakan seiring dengan meningkatnya konsentrasi gelatin. Perbedaan kombinasi gelatin kulit kaki ayam dan soy protein isolate untuk membentuk edible film tidak memberikan pengaruh nyata pada kekuatan tarik (tensile strenght), dan kemuluran (elongation), namun berpengaruh nyata pada laju transmisi uap air (Water Vapour Transmision Rate). Kombinasi 95:5 protein gelatin kulit kaki ayam dan soy protein isolate menghasilkan edible film yang terbaik.

(Kata kunci: Edible film, Gelatin kaki ayam, Soy protein isolate)

\section{ABSTRACT}

The study was aimed to combine chicken legs skin gelatin and soy protein isolate as a raw material for edible films. The research materials used were chicken leg skin and soy protein isolate. There were two stages in the experimental. The first stage was processing of gelatin from chicken leg skin which soaked in $0.1 \% \mathrm{NaOH}, 0.1 \%$ sulfuric acid, and $0.4 \%$ citric acid. The second stage was preparation of edible films. The material films were combination of soy protein isolate and gelatin chicken legs skin with different ratio $(75: 25,80: 20,85: 15,90: 10$, and 95:5). Statistical analysis were carried out by one Anova and the mean difference was tested using Duncan's New Multiple Range Test. SDS-PAGE result showed the band pattern of the molecule was dominated by the protein molecules of gelatin, SDS-PAGE pattern showed no changed of collagen protein bands. The results of the analysis of amino acid content of edible films using HPLC produced the largest amino acid residue composition in each treatments was glysin ie 29.42\%, 37.88\%, 38.32\%, 39.28\% and 39.17\% respetively. This result described that protein profile of HPLC was dominated protein from chicken leg gelatin. Observations with a scanning electron microscope showed the cross-linking between protein molecules of gelatin and soy protein isolate. Different combinations of chicken legs skin gelatin and soy protein was not different on the tensile strength, and elongation, but there were a significant difference on water vapor transmission rate. The best quality of edible films formed was on the ratio 95:25.

(Keywords: Edible films, Chicken leg gelatin, Soy protein isolate)

\footnotetext{
$\bar{*}$ Korespondensi (corresponding author):

Telp. +6285643403871

E-mail: hasdarmuhammad@gmail.com
} 


\section{Pendahuluan}

Kaki ayam merupakan hasil ikutan pemotongan ayam yang pemanfaatannya terbatas karena kandungan dagingnya sedikit dan tinggi kandungan kulit serta tulangnya. Kulit dan tulang tersusun dari jaringan ikat padat yang kaya akan kolagen. Hidrolisis partikel kolagen akan menghasilkan gelatin. Gelatin banyak dimanfaatkan untuk bahan pangan sebagai bahan penstabil, pembentuk gel, pengikat, pengental, pengelmulsi, perekat dan pembungkus makanan yang dapat dimakan (edible film). Gelatin di Indonesia merupakan barang impor yang sebagian besar berasal dari Eropa dan Amerika. Persentase aplikasi gelatin di bidang pangan mencapai $60 \%$ dari total gelatin impor di dunia. Kontribusi gelatin dari sapi sebesar 33\% dan $27 \%$ gelatin yang berasal dari babi (Wiyono, 2001), sehingga alternatif yang cukup potensial untuk dikembangkan adalah gelatin yang berbahan baku kulit kaki ayam, mengingat produksi ayam di Indonesia dari tahun ke tahun mengalami peningkatan seiring pemenuhan gizi masyarakat Indonesia. Salah satu sifat gelatin adalah dapat berubah secara reversibel dari bentuk sol ke gel, membengkak atau mengembang dalam air dingin serta mampu membentuk film (Schrieber dan Gareis, 2007), sehingga gelatin sering digunakan dalam pembuatan kemasan biodegrable seperti edible film.

Edible film merupakan lapisan tipis yang dapat dikonsumsi dan sering digunakan sebagai pelapis makanan (Bourtoom, 2008). Keuntungan penggunaan edible film untuk kemasan bahan pangan adalah memperpanjang umur simpan produk serta tidak mencemari lingkungan karena edibel film ini dapat dimakan bersama produk yang dikemasnya. Penggunaan kemasan plastik, kaleng dan styrofoam selama ini ternyata memberikan masalah penumpukan limbah karena sifatnya yang tidak mudah terurai secara alami, sehingga edible film menjadi salah satu solusi permasalahan ini.

Kesadaran konsumen akan kualitas produk pangan untuk kesehatan manusia dan lingkungan menjadi alasan utama dilakukannya penelitianpenelitian terkait biodegrable film yang berasal dari kombinasi protein hewani dan nabati. Alternatif lain untuk meningkatkan fungsi protein edible film dengan cara memodifikasi jaringan polimer melalui penggabunga rantai polimer antara dua protein yang berbeda sumber, sehingga bisa terjadi cross linking asam-asam amino pada rantai fungsional kedua protein melalui proses pemanasan, kimia, atau enzimatis (Chambi dan Grosso, 2006).

Penelitian Cao et al. (2007) berhasil membuat edible film dari kombinasi gelatin bovine tipe B dengan soy protein isolate dengan proses pe- manasan. Chambi dan Grosso (2006) di dalam penelitiannya mampu membuat edible film dari kombinasi gelatin bovine tipe $\mathrm{B}$ dengan kasein melalui proses enzimatis. Penelitian-penelitian ini memberikan informasi akan potensi pengembangan edible film dari hidrokoloid protein. Pengembangan edible film dari kombinasi protein hewani dan nabati merupakan hal yang sangat menarik dan sangat inovatif dalam pengemasan pangan.

\section{Materi dan Metode}

\section{Materi}

Materi penelitian yang digunakan adalah kulit kaki ayam broiler strain Hubbart umur 40 hari sebanyak 860 lembar yang diperoleh dari tempat pemotongan ayam di Kabupaten Sleman. Bahan ini diperoleh dalam bentuk potongan kaki ayam sehingga kulit masih melekat di tulang. Soy protein isolate yang dipergunakan adalah merek Sun Green yang diperoleh dari perusahan makanan kecil.

Bahan kimia yang yang digunakan untuk perendaman kulit kaki ayam adalah $\mathrm{NaOH}$, asam sulfat, asam sitrat, dan aquadest. Bahan plasticizer yang digunakan adalah gliserin. Alat untuk pelaksanaan penelitian yaitu timbangan analitis (merk Sartorius), pisau, penjepit, alat-alat gelas, oven (merk Memert), water bath, termometer, kertas saring biasa, visikosimeter, dan universal Testing Machine (Test Zwick).

\section{Metode}

Penelitian diawali dengan pengulitan kaki ayam kemudian dilakukan penghilangan lemak kulit kaki ayam broiler dan dilanjutkan dengan pembuatan gelatin kulit kaki ayam broiler yang direndam dalam $\mathrm{NaOH} 0,1 \%$, asam sulfat $0,1 \%$, dan asam sitrat $0,4 \%$ selama 40 menit secara berurutan, kemudian dilakukan ekstraksi dengan suhu $70^{\circ} \mathrm{C}$ selama 24 jam mengggunakan water bath dan selanjutnya dilakukan penyaringan (Wulandari, 2006), kemudian dioven selama 24 jam pada suhu $55^{\circ} \mathrm{C}$ untuk mendapatkan gelatin kering.

Metode pembuatan edible film mengacu pada metode Chambi dan Grosso (2006) dengan modifikasi level soy protein isolate. Perbandingan kombinasi gelatin kulit kaki ayam broiler dan soy protein isolate adalah 75:25, 80:20, 85:15, 90:10, 95:5. Gelatin kulit kaki ayam dan soy protein isolate masing-masing dilarutkan dengan aquadest kemudian dipanaskan dengan water bath with stirring yang termodifikasi pada suhu $55^{\circ} \mathrm{C}$ selama 30 menit. Larutan gelatin kulit kaki ayam dan soy protein isolate dicampur dengan penambahkan gliserin sebanyak $0,1 \%$, pada suhu $55^{\circ} \mathrm{C}$ menggunakan water bath with stirring yang termodifikasi selama 30 menit, kemudian dikeringkan dengan 
menggunakan oven selama 24 jam pada suhu $50^{\circ} \mathrm{C}$ untuk mendapatkan lembaran edible film. Perlakuan ini diulang sebanyak 6 kali dan hasilnya direrata.

\section{Parameter percobaan}

Variabel pengujian kimia dan fisik penelitian ini meliputi: pengujian berat molekul, asam amino, morfologi edible film, kekuatan tarik edible film, kemuluran edible film, dan laju transmisi uap air.

SDS-PAGE (Sodium Dodecyl Sulfate Poliacrylamide Gel Electrophoresis) adalah metode yang digunakan untuk pengujian berat molekul seperti yang diuraikan oleh Laemmli (1970). Formula yang disiapkan adalah $10 \%$ gel pemisah (resolving gel) dan 5\% stacking gel dengan bahan preparsi yaitu $30 \%$ Akrilamide (w/v), 1.5 Tris- $\mathrm{HCl}$ $(\mathrm{pH} 8.8), 10 \%$ SDS, $10 \%$ APS. Marker yang digunakan adalah miosin $205 \mathrm{kDa}$, $\beta$ galaktosidase $116 \mathrm{kDa}$, bovine serum albumin $67 \mathrm{kDa}$, ovalbumin $45 \mathrm{kDa}$, kabonik anhidrase $29 \mathrm{kDa}$.

Untuk pengujian asam amino, bubuk edible film sebanyak $60 \mathrm{mg}$ ditambahkan $4 \mathrm{ml} \mathrm{HCL} 6 \mathrm{~N}$ dan dipanaskan selama 24 jam pada suhu $110^{\circ} \mathrm{C}$, selanjutnya dinetralkan ( $\mathrm{pH} 7)$ dengan $\mathrm{NaOH} 6 \mathrm{~N}$ kemudian diencerkan hingga $100 \mathrm{ml}$. Sampel yang telah dinetralkan kemudian disaring dengan kertas saring Whatman $0,2 \mu \mathrm{m}$. Sampel diambil sebanyak $25 \mathrm{ml}$ dan ditambahkan OPA (Orthophalaldehid) sebanyak $300 \mu \mathrm{l}$ kemudian diaduk selama 5 menit, selanjutnya dimasukan ke injektor HPLC (High performance liquid Cromatografi) sebanyak $20 \mu \mathrm{l}$.

Analisis morfologi terhadap edible film diamati dengan SEM (Scanning Electro Microscopy) type JEOL JSM-5310 LV pada pembesaran $100 \mathrm{kali}$ untuk luas penampang datar dan perbesaran 750 kali untuk luas penampang melintang.

Kekuatan tarik dari edible film diuji dengan menggunakan Lloyd's universal Testing Instrument machine tipe LRX 5K. Kemuluran dinyatakan sebagai gaya maksimum yang diberikan pada film sampai sobek (Newton) dibagi luas penampang film $\left(\mathrm{m}^{2}\right)$, sedangkan pemanjangan dihitung sebagai $\left[\left(\Delta \mathrm{t}_{\max } \mathrm{x}\right.\right.$ test speed $) /$ panjang film awal $] \mathrm{x} 100 \%$.
Laju transmisi uap air diuji dengan gravimetric dessicant method seperti yang dijelaskan oleh Shiku et al. (2004). Film yang diuji dipasang pada cawan yang berisi $10 \mathrm{~g}$ silika gel. Bagian tepi cawan dan film ditutup dengan isolasi. Cawan dan film ditimbang dan dilakukan pengamatan selama 1-7 jam. Data yang diperoleh dibuat dengan persamaan regresi linier, sehingga diperoleh slope kenaikan berat cawan.

\section{Analisis data}

Pengelolaan data penelitian ini menggunakan analisis variansi pola searah dan apabila terdapat beda nyata diteruskan diuji lanjut dengan uji Duncan's New Multiple Range Test.

\section{Hasil dan Pembahasan}

\section{Berat molekul}

Susunan biopolimer dapat dilihat dengan menggunakan analisis SDS-PAGE disajikan pada Gambar 1. Gambar 1 menunjukkan profil molekul protein yang diproduksi dari berbagai jenis kombinasi gelatin kulit kaki ayam dan soy protein isolate, dimana pola band dari molekul didominasi oleh molekul protein dari gelatin yang ditunjukkan dengan tidak berubahnya pola bands dari setiap edible film yaitu tipe $\alpha_{1}$ dan $\alpha_{2}$. Pola migrasi pita peptida (protein) termasuk tipe I yang terdiri dari dua rantai peptida kembar (Prayitno, 2007). Penelitian Chambi dan Grosso (2006) juga memperlihatkan pola band yang sama pada semua kombinasi gelatin sapi tipe B dengan kasein.

Gambar 1 terlihat ada pita berwarna lebih gelap di atas band $\alpha_{1}$ dan $\alpha_{2}$ di setiap sumuran edible film. Hal tersebut menunjukkan adanya ikatan antara molekul protein gelatin kulit kaki ayam dengan molekul protein soy protein isolate, artinya berat molekul dari edible film masih dikatakan besar. Pita protein dengan berat molekul tinggi yang paling menonjol diperlihatkan pada edible film kombinasi 75:25, sedangkan pada kombinasi edible film yang lain masih terlihat tidak

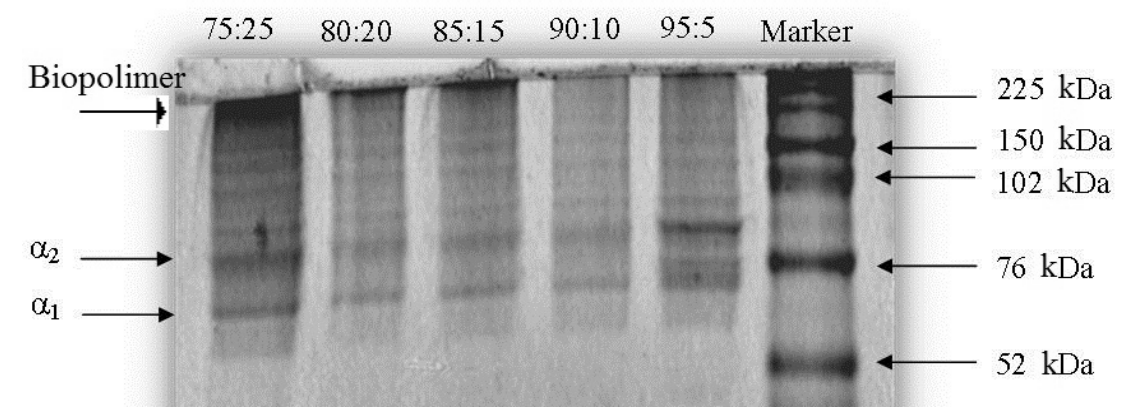

Gambar 1. Hasil elektrophoresis profil protein edible film dengan perbedaan komposisi gelatin dan soy protein isolate (elektrophoresis result of edible film protein profile with different gelatin and soy protein isolate composition). 
begitu jelas. Pita gelap tersebut mengindikasikan berat molekul masih ada di kisaran $225 \mathrm{kDa}$, pada kisaran $52 \mathrm{kDa}$ sampai $225 \mathrm{kDa}$ ini tidak terdenaturasi oleh panas saat pengeringan. Bagian bawah gel menunjukkan tidak adanya pita protein diperlihatkan dengan pita agak samar-samar pada pola sumuran SDS-PAGE, artinya tidak terjadi ikatan yang baik antar kedua molekul protein pada saat pengeringan edible film. Berat molekul edible film pada penelitian ini lebih tinggi dibandingkan dengan berat molekul protein gelatin kulit kaki ayam yang dihasilkan oleh Wulandari (2006) yang berkisar 9,233 $\mathrm{kDa}$ sampai 28,767 $\mathrm{kDa}$, dengan metode preparasi yang sama.

Peningkatan berat molekul ini dimungkinkan adanya ikatan silang antarmolekul protein gelatin kulit kaki ayam dan soy protein isolate dan menghasilkan struktur baru dengan berat molekul yang tinggi. Berat molekul berkaitan langsung dengan sifat dan kemampuan pembentukan edible film, yaitu semakin tinggi berat molekul, maka edible film yang dihasilkan semakin baik (Sobral dan Habitante, 2001). Salah satu penyebab meningkatnya berat molekul protein edible film yaitu keberadaan asam amino sulfur (sistin dan sistein), dimana isolat protein kedelai adalah salah satu dari protein yang mengandung asam amino sistin dan sistein (Gennadios et al., 1993).

\section{Asam amino}

Hasil analisis kandungan asam amino edible film menggunakan HPLC (High Performance Liquid Cromatograf) yang disajikan pada Tabel 1. Tabel 1 menunjukkan penambahan soy protein isolate ternyata memberikan efek yang besar terhadap komposisi asam amino edible film.
Meningkatnya konsentrasi gelatin dalam edible film ternyata mampu meningkatkan konsentrasi asam amino. Komposisi residu asam amino terbesar adalah glysin yaitu 29,$42 ; 37,88 ; 38,32 ; 39,28$; dan $39,17 \%$, masing-masing dihasilkan dari kombinasi edible film 75:25, 80:20, 85:15, 90:10, 95:5 secara berurutan. Berdasarkan hasil penelitian ini menggambarkan bahwa protein yang dihasilkan dari edible film dapat dipastikan sebagian besar berasal dari kolagen karena komposisi terbesar adalah glysin.

Komposisi asam amino edible film pada Tabel 1 mengalami peningkatan jika dibandingkan dengan komposisi gelatin, asam amino glysin edible film kombinasi 80:20, 85:15, 90:10 dan 95:5 masih sama dengan kandungan glysin pada gelatin kulit kaki ayam yang dihasilkan oleh Wulandari (2006) yaitu $37,90 \%$, hal ini disebabkan karena metode ekstraksi gelatin yang digunakan sama yaitu $\mathrm{NaOH}$, asam sulfat, dan asam sitrat, akan tetapi untuk edible film komposisi 75:25 asam amino glysin mengalami penurunan menjadi $29,42 \%$, hal ini mungkin disebabkan oleh kosentrasi kolagen dalam edible film yang lebih rendah dan kosentrasi soy protein isolate yang meningkat.

Di sisi lain terjadi peningkatan hampir pada semua jenis asam amino, namun yang paling menonjol adalah untuk jenis asam amino aspartat, dan glutamat, sehingga mempengaruhi seluruh komposisi asam amino edible film. Komposisi asam amino edible film ini lebih besar dibandingkan komposisi asam amino bahan dasarnya yaitu gelatin kulit kaki ayam dan soy protein isolate. Peningkatan komposisi asam amino ini dikarenakan adanya ikatan silang antarmolekul protein gelatin dan kedelai. Menurut Liyanage et al. (2001) bahwa

Tabel 1. Komposisi asam amino edible film kombinasi gelatin kulit kaki ayam dan soy protein isolate (amino acid composition of edible film combination of chicken leg skin gelatin and soy protein isolate)

\begin{tabular}{lrrrrr}
\hline \hline \multirow{2}{*}{$\begin{array}{c}\text { Jenis asam amino } \\
\text { (amino acid) }\end{array}$} & \multicolumn{5}{c}{ Kombinasi edible film (\%) } \\
\cline { 2 - 5 } Aspartate & $75: 25$ & $80: 20$ & $85: 15$ & $90: 10$ & $95: 5$ \\
Glutamate & 9,48 & 6,04 & 7,37 & 6,31 & 7,36 \\
Serine & 6,80 & 8,17 & 1,66 & 4,58 & 5,20 \\
Histidine & 5,35 & 4,30 & 3,69 & 4,67 & 3,20 \\
Glysine & 0,77 & 0,34 & 0,24 & 0,29 & 0,39 \\
Arginine & 29,42 & 37,88 & 38,23 & 39,28 & 39,17 \\
Alanine & 7,80 & 7,78 & 8,24 & 7,72 & 8,37 \\
Tyrosine & 10,91 & 13,01 & 13,90 & 13,57 & 14,16 \\
Methionine & 1,15 & 4,21 & 5,18 & 4,94 & 0,87 \\
Valine & 4,63 & 3,53 & 3,32 & 3,34 & 2,82 \\
Fenillatanine & 4,63 & 3,53 & 3,32 & 3,34 & 2,82 \\
Isoleusine & 2,74 & 1,99 & 1,78 & 1,80 & 1,62 \\
Leusine & 2,76 & 1,81 & 1,75 & 1,48 & 1,59 \\
Lysine & 5,85 & 3,96 & 3,65 & 3,53 & 3,37 \\
\hline
\end{tabular}


protein kedelai mengandung sebagian besar asam amino yang bersifat polar (hidrofilik) seperti asam aspartat, asam glutamat, dan lisin, serta fraksi kecil non polar (hidrofobik) seperti asam amino leusin, prolin dan alanin. Menurut Swain et al. (2004) aspartat dan glutamat adalah asam amino yang bersifat asam yang dapat mempengaruhi komposisi asam amino edible film yang diproduksi dari protein kedelai.

\section{Morfologi}

Hasil Scanning electron micrograph (SEM) permukaan dan penampang melintang edible film yang produksi dari gelatin kulit kaki ayam dan soy protein isolate disajikan pada Gambar 2.

Mikrostruktur dari edible film dapat dilihat dari hasil scanning electron micrograph pada bagian permukaan datar dan melintang edible film dari kombinasi gelatin kulit kaki ayam dan soy protein isolate. Gambar (a-1) menunjukkan struktur yang berbeda antara gelatin dan soy protein isolate, terjadi retakan pada permukaan datar dan melintang edible film, retakan inilah yang menyebabkan rendahnya kuat tarik, rendahnya kemuluran, dan tingginya laju transmisi uap air edible film kombinasi 75:25, hal ini disebabkan oleh kosentrasi soy protein isolate yang tinggi dan penggunaan suhu $50^{\circ} \mathrm{C}$ pada saat pengeringan edible film. Ketika kadar air dihilangkan pada saat pengeringan maka tingkat konformasi protein berubah dan tingkat protein menentukan berlangsungnya ikatan hidrofobik, ikatan ionik, hidrogen, dan interaksi yang dapat dibangun antara rantai protein (Denavi et al., 2009) dan pengeringan merupakan proses pembentukan struktur film baru dari protein kedelai (Bourtoom, 2008).
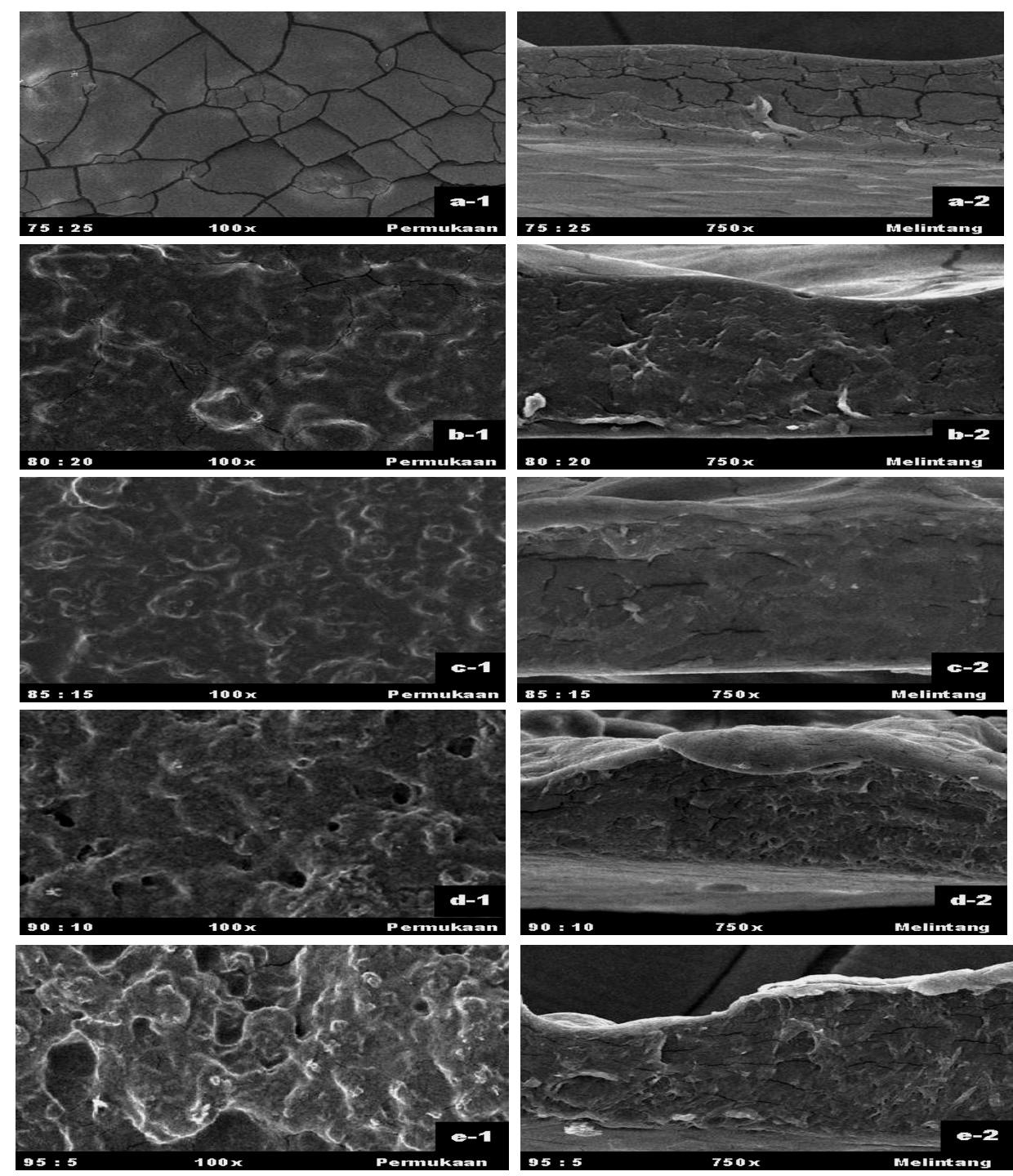

Gambar 2. Scanning electron micrograph luas permukaan (-1) dan luas penampang melintang (-2) edible film kombinasi 75:25 (a), 80:20 (b), 85:15 (c), 90: 5 (d) dan 95:5 (e) (scanning electron micrograph of surface area $(-1)$ and cross-sectional area (-2) edible films combination of 75:25 (a), 80:20 (b), 85:15 (c), 90:5 (d) and 95:5(e)). 
Pada kasus pencampuran gelatin dan soy protein isolate dengan kombinasi 80:20 mulai terjadi homogenisasi antara keduanya (gambar b1 dan b2), ini ditunjukkan dengan berkurangnya retakan serta mulai membangun struktur edible film yang baik dimana struktur fibril kolagen gelatin mulai menyatu dengan partikel soy protein isolate. Hal ini sama dengan penelitian Chambi dan Grosso (2006) yang mencampur gelatin dan kasein melalui pemanasan. Pada perbandingan 85:15 sudah membentuk cross linking dan menguatkan perbandingan sebelumnya bahwa retakan samakin berkurang dengan meningkatnya konsentrasi gelatin (gambar c), namun partikel-partikel soy protein masih membentuk gumpalan. Konsentarsi gelatin sangat menentukan karakteristik edible film yang terbentuk dari kombinasi gelatin dan soy protein isolate (Cao et al., 2007).

Struktur tripel heliks kolagen gelatin kulit kaki ayam mampu bercampur dengan soy protein isolate melalui proses pemanasan, seperti yang ditunjukkan pada gambar d dan e, dimana gumpalan semakin berkurang dan struktur molekul lebih halus, namun konsentrasi dari soy protein isolate tidak lebih dari 5\% (v/v). Penelitian Erwanto et al. (2005) yang mencampur 5\% bovine collagenpeptida dengan $1 \%$ soybean protein dengan proses pemanasan menunjukkan adanya pencampuran meskipun molekul-molekulnya masih lebih kasar.

\section{Kekuatan tarik (tensile strength) dan kemuluran (elongation)}

Tensile strength menunjukkan gaya maksimum yang diperlukan untuk memutuskan edible film. Edible film dengan kekuatan tarik tinggi akan mampu melindungi produk yang dikemasnya dari ganggunan mekanis dengan baik (Suryaningrum et al., 2005). Kemuluran dan kekuatan tarik disajikan pada Gambar 3 dan 4.

Gambar 3 menunjukkan bahwa meningkatnya konsentrasi gelatin pada komposisi edible film akan meningkatkan tensile strength, edible film menjadi lebih transparan, homogeneus dan tidak mudah patah. Tensile strength pada penelitian ini sejalan dengan penilitian Chambi dan Grosso (2006) yang melaporkan bahwa tensile strength edible film berbahan dasar gelatin dan kasein meningkat disebabkan adanya peningkatan konsentrasi kolagen dalam gelatin. Tensile strength pada penelitian ini tertinggi pada kombinasi 95:5 dan terendah kombinasi 75:25 serta tidak berbeda nyata antara kombinasi edible film $(\mathrm{P}>0.05)$.

Elongation menunjukkan perubahan panjang film maksimum saat memperoleh gaya tarik sampai film putus dibandingkan dengan panjang awalnya. Besarnya nilai elongation selalu berbanding terbalik dengan nilai tensil strength. Elongation dikatakan baik jika nilainya lebih dari $50 \%$ dan dikatakan buruk jika nilainya kurang dari 10\% (Krochta dan De Muller-Johnson, 1997).

Arvanitoyannis et al. (1997) menyatakan bahwa besarnya kekuatan tarik ditentukan oleh struktur jaringan yaitu bentuk anyaman dan kandungan protein dalam kolagen pada gelatin edible film. Selanjutnya Cho et al. (2007) menyatakan bahwa tensile strength menurun pada penelitian edible film yang dibuat dari membran konsentrat protein kedelai dikarenakan tidak semua partikel soy protein isolate berpartisipasi dalam pembentukan film. Gelatin mempunyai sifat mekanik yang lebih baik dari soy protein isolate sebab gelatin lebih fleksibel dan elastis (Lee et al., 2004).

\section{Laju transmisi uap air}

Hasil pengujian laju transmisi uap air edible film yang diproduksi dari gelatin kaki ayam dan soy protein isolate, disajikan pada Gambar 5.

Laju transmisi uap air menunjukkan kecepatan menembusnya uap air (per gram per detik) persatuan luas edible film atau kemampuan film untuk menghambat transmisi air, maka

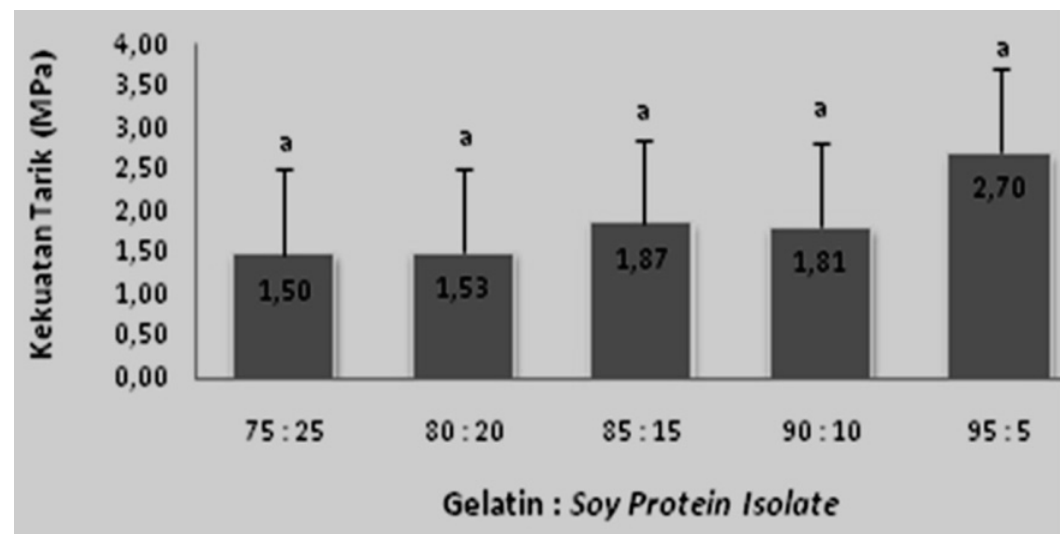

Gambar 3. Nilai tensile strength edible film yang diproduksi dari gelatin kaki ayam dan soy protein isolate. Huruf a pada diagram batang menunjukkan tidak berbeda nyata $(\mathrm{P}>0,05)$ (tensile strength of edible film from chicken leg skin gelatin and soy protein isolate combination. a letter at chart bar showed non significant $(P>0.05))$. 


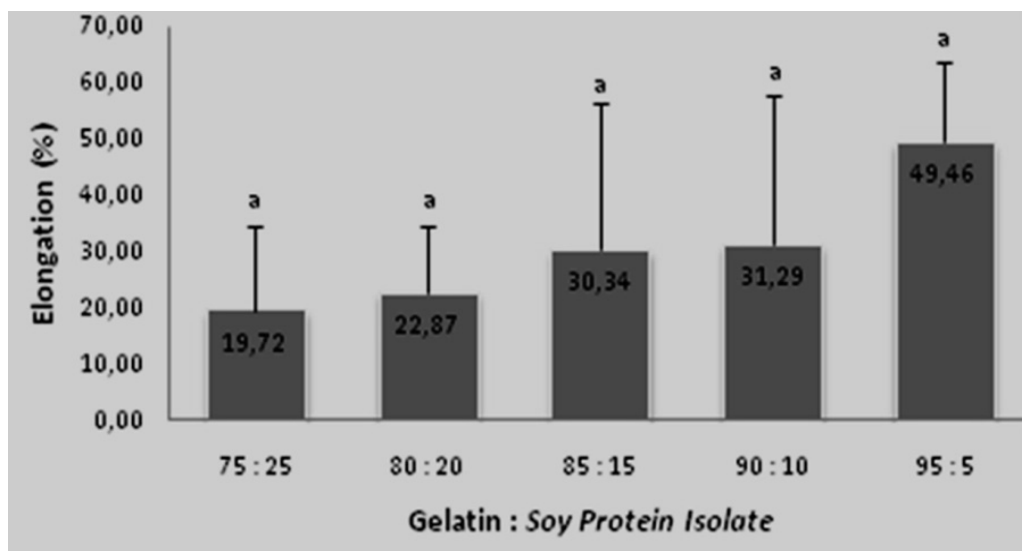

Gambar 4. Nilai elongation edible film yang diproduksi dari gelatin kaki ayam dan soy protein isolate. Huruf a pada diagram batang menunjukkan tidak berbeda nyata $(\mathrm{P}>0,05)$ (elongation value of edible film from chicken leg skin gelatin and soy protein isolate combination. a letter at chart bar showed non significant $(P>0.05))$.

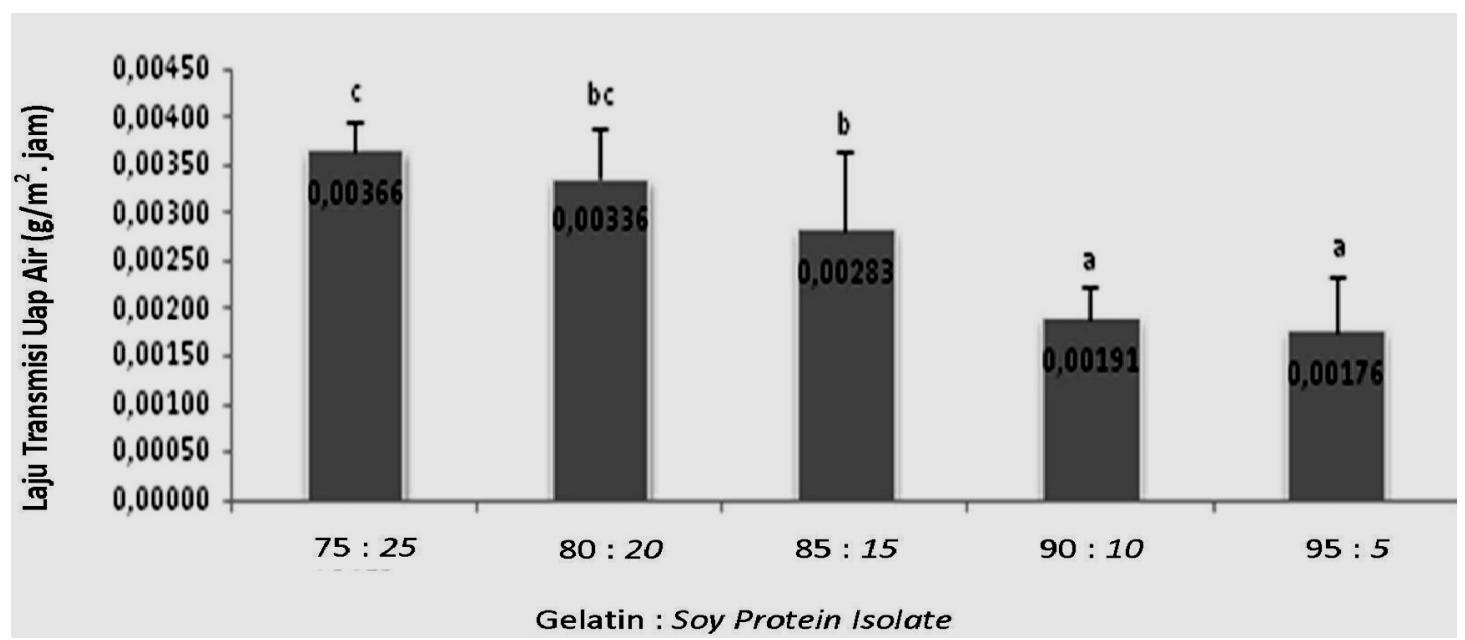

Gambar 5. Nilai laju transmisi uap air edible film yang diproduksi dari gelatin kaki ayam dan soy protein isolate.

Huruf $\mathrm{a}, \mathrm{b}$, dan $\mathrm{c}$ pada diagram batang menunjukkan perbedaan nyata $(\mathrm{P}<0,05)$ (the value of water vapor transmission rate of edible film produced from chicken feet gelatin and soy protein isolate. Letters $a, b$, and $c$ on $a$ bar chart shows the significant difference $(P<0.05))$.

permeabilitasnya terhadap uap air harus serendah mungkin (Gontard et al., 1993). Pada penelitian ini laju transmisi uap air terbaik pada edible film kombinasi 95:5. Jumlah kolagen dalam edible film kombinasi 95:5 dan 90:10 mampu memperbaiki struktur film dan sifat fisik terutama memperkecil laju transmisi uap air. Hal ini disebabkan oleh jumlah kosentrasi kolagen yang tinggi dalam edible film ternyata mampu meningkatkan ikatan struktur film (Cao et al., 2007). Di mana ikatan struktur film dipengaruhi oleh berat molekul dan panjang ikatan rantai asam amino penyusun edible film, semakin besar panjang rantai asam amino membuat berat molekul semakin besar, sehingga lapisan film pada edible film semakin rapat (Junianto et al., 2006).

Edible film kombinasi 75:25 serta 80:20 memiliki laju transmisi uap air yang tinggi dikarenakan ikatan hidrofilik antara kedua bahan edible film yang tidak mampu bersatu dalam edible film, sehingga mempengaruhi struktur air dalam edible film yang membuat sifat fisik menjadi menurun.

Terjadi perbaikan struktur mekanik pada edible film 85:15, di mana laju transmisi uap air mulai rendah. Hal ini disebabkan oleh ikatan hidrogen polimer menunjukkan peningkatan. Film yang mengandung protein yang tinggi memiliki sifat barrier yang baik disebabkan oleh polimer yang memiliki ikatan hidrogen yang besar dan mengandung gugus hidroksil yang rendah (Jongjareonrak et al., 2006). Faktor lain yang mempengaruhi laju transmisi uap air edible film adalah gliserol yang digunakan sebagai plasticizer agar film yang dihasilkan lebih halus dan lebih luwes. Gliserol adalah plasticizer yang bersifat hidrofilik yang relatif kecil dan mudah disisipkan diantara rantai protein dan membentuk ikatan hidrogel dengan gugus amida dan protein gluten (Cao et al., 2007). 


\section{Kesimpulan dan Saran}

\section{Kesimpulan}

Berat molekul edible film dari semua kombinasi gelatin kulit kaki ayam dan soy protein isolate sama berkisar di $52-102 \mathrm{kDa}$. Kombinasi gelatin kulit kaki ayam dan soy protein isolate meningkatkan kandungan asam amino. Kualitas fisik membaik seiring dengan meningkatnya konsentrasi kolagen gelatin, serta tidak memberikan pengaruh pada kuat tarik (tensile strenght), dan kemuluran (elongation), namun berpengaruh pada laju transmisi uap air (Water Vapour Transmision Rate) edible film. Edible film terbaik yang dihasilkan pada penelitian ini adalah kombinasi 95:5.

\section{Saran}

Penelitian lanjutan dapat dilakukan dan disarankan penelitian edible film kombinasi kulit kaki ayam dan soy protein isolate dengan bantuan enzim untuk memudahkan reaksi ikatan silang serta penelitian pengukuran lama penyimpanan edible film kombinasi kulit kaki ayam dan soy protein isolate terhadap aktivitas mikroorganisme perusak.

\section{Daftar Pustaka}

Arvanitoyannis, I., E. Psomiadou, A. Nakayama, S. Aiba, and N. Yamamoto. 1997. Edible film made from gelatin, soluble starch and polyols, Part 3. Int. J. Food Chem. 60(4): 593-604.

Bourtoom, T. 2008. Edible films and coatings: characteristics and properties. Int. J. Food Res. 15(3): 1-9.

Cao, N., Y. Fu, and J. He. 2007. Preparation and physical properties of soy protein isolate and gelatin composite films. Int. J. Food Hydro. 21: 1153-1162.

Chambi, H., and C. Grosso. 2006. Edible film produced whit gelatin and casein cros-linked whit transgluminase. Int. J. Food Res. 39: 458-466.

Cho, S.Y., J.W. Park, H. Batt, and R. Thomas. 2007. Edible films made from membrane processed soy protein concentrates. Lebensmittel-Wissenschaft und- J. Technologie. 40: 418-423.

Denavi, G., D.R. Tapia-Blácido, M.C. Añón, P.J.A. Sobral, A.N. Mauri, and F.C. Menegalli. 2009. Effects of drying conditions on some physical properties of soy protein films. J. Food Eng. 90: 341-349.

Erwanto, Y., S. Kawahara, K. Katayama, A.M. Ahhmed, K. Yamauchi, K.B. Chin, and M. Muguruma. 2005. Effect of existence of exogenous protein on physicochemical properties of heat and transglutaminaseinduced bovine collagen-peptide gel. J. Food Sci. 70: 505-509.

Gennadios, A., A.H. Brandenburg, C.L. Weller, and R.F. Testin. 1993. Effect of $\mathrm{pH}$ on properties of wheat gluten and soy protein isolate films. J. Agr. Food Chem. 1835-1839.

Gontard, N., S. Guilbert, and J.L. Cuq. 1993. Water and glyserol as plasticizer affect mechanical and water barrier properties at an edible wheat gluten film. J. Food Sci. 58(1): 206211.

Jongjareonrak, A., S. Benjakul, W. Visessanguan, T. Prodpran, and M. Tanaka. 2006. Characterization of edible films from skin gelatin of brown stripe red snapper and big eye snapper. J. Food Hidro. Elsevier. 492501.

Junianto, K. Haetami, dan I. Maulina. 2006. Produksi gelatin dari tulang ikan dan pemanfaatannya sebagai bahan dasar pembuatan cangkang kapsul. Laporan Penelitian Hibah Bersaing IV Tahun I. Fakultas Perikanan Dan Ilmu Kelautan Universitas Padjadjaran.

Krochta, J.M. and C. De Muller-Johnson. 1997. Edible and biogedrable polymer films. J. Food Technol. 51(2): 61-74.

Laemmli, U.K. 1970. Cleavage of structural proteins during the assembly of the head bacteriofaget. Nature. 227: 680-685.

Lee, K.Y., J. Shim, and H.G. Lee. 2004. Mechanical properties of gellan and gelatine composite films. J. Carbohidrate polymers. 251-154.

Liyanage, D.S., M. Tillekeratne, and S. Hewage. 2001. Preparatin and characterizationof edible soya protein films. J. Natn. Sci. 29 (3\&4): 137-145.

Prayitno. 2007. Ekstraksi kolagen cakar ayam dengan berbagai jenis larutan asam dan lama perendamannya. J. Animal Production. 9(2): 99-104.

Schrieber, R. and H. Gareis. 2007. Gelatine Handbook Theory and Industrial Practice. WILEY-VCH Verlag GmbH \& Co KgaA.

Shiku, Y., P.Y. Hamaguchi, S. Benjakul, W. Visessanguan, and M. Tanaka. 2004. Effect of Surimi Quality on Properties of Edible Films Based on Alaska Pollack. Food Chem. Elsevier. 493-499.

Sobral, P.J.A. and A.M.Q.B. Habitante. 2001. Phase transitions of pig skin gelatin. J. Food Hydrocolloids. 15: 377-382.

Suryaningrum, D.T.H., J. Basmal, dan Nurochmawati. 2005. Studi pembuatan edible film dari karaginan. J. Penelitian Perikanan Indonesia. 11(4): 1-13. 
Swain, S.N., S.M. Biswal, P.K. Nanda, and P.L. Nayak. 2004. Biodegradable soy-based plastics: opportunities and challenges. J. Polymers Enviro. 12(1): 35-42.

Wiyono, V.S. 2001. Gelatin Halal Gelatin Haram. Jurnal Halal LPPOM-MUI. No. 36: 26-27.
Wulandari, D. 2006. Ekstraksi dan karateristik gelatin dari kulit kaki ayam. Tesis. Program Studi Ilmu Peternakan Jurusan Ilmu-Ilmu Peternakan Universitas Gadjah Mada. Yogyakarta. 